\title{
Mites Associated with the Red Palm Weevil, Rhynchophorus ferrugineus Oliver in Saudi Arabia with a Description of a New Species
}

\author{
Z. M. Al-Dhafar and A. M. Al-Qahtani \\ Department of Biology, Dammam University, Dammam, Eastern Province, 31481, Saudi Arabia, \\ moth158@yahoo.com
}

\begin{abstract}
The red palm weevil (RPW) Rhynchophorus ferrugineus Oliver is an economically important pest of palm in Al-Hassa (Eastern Province of Saudi Arabia). The RPW was noted associated with mites during May -- June 2009. Three mite species were found. One of which Aegyptus alhassa n. sp. (Gamasida, Trachyuropodidae) as a parasite collected from eggs, larvae, pupae cocoons and under the elytron of insect adult was described. The second mite species Sejus sp. may feed on fungi or organic debris, while the acarid hypopial stage may feed on dead insects.
\end{abstract}

Key Words: Rhynchophorus ferrugineus, Mite, Aegyptus alhssa, n. sp., Sejus sp., Acarid hypopus, Al-hssa, Saudi Arabia

\section{INTRODUCTION}

The red palm weevil Rhynchophorus ferrugineus Oliver is an important pest of palm in many parts of the world (Faleiro et al., 2002). The RPW damage symptoms are recognized by the presence of tunnels in the trunk, oozing of thick yellow to brown fluid from the tree and the appearance of chewed-up plant tissue and around openings in the trunk (Kaakeh et al., 2201).

The occurrence of this pest in the Middle East was firstly reported from United Arab Emirates in 1985, followed by the Kingdom of Saudi Arabia, AlQatef in 1987. The Species, Trichouropoda patavina, Iphidosoma sp., Hypoaspis sardoa Berlese, Parasitis zaheri Hafeze \& Nasr, Scutacarus sp., Histiostoma sp. (El-Sharabasy, 2010) and Fuscuoropoda marginata (Koch), Aegyptus rhynchophorus El Beshlawy \& Allam and the fly insect Ceratitis capitata Weid were recorded associated with the weevils wastes (El Beshlawy and Allam, 2007). Uropodidae is a cosmopolitan large family consisting of fungivorous, insect associations and occasionally predators (Krantz, 1978). Many uropodids occur commonly in litter, detritus, soil, moss, rotting wood and nests of insects (Petrova et al., 2004). Uropodid mites are considered to be scavengers (Moser et al., 2005).

In this study, mites associated with the RPW as natural enemies were surveyed in Al-Hassa, Saudi Arabia.

\section{MATERIALS AND METHODS}

Eggs, larvae, pupae and ad a PW ere collected from trunks of infested paini uw.w in Al-Hassa (Eastern Province of Saudi Arabia) during May-June 2009. Specimens were placed in separated sterilized jars with sugarcane as diet at $37 \pm 2^{\circ} \mathrm{C}$ and
$70 \pm 5$ RH. Mites associated with the RPW individuals were observed under the elytron, on the surface of pupae cocoons and eggs were separated and photographed for morphological studies (Figs. 1-3).

\section{RESULTS AND DISCUSSION}

The Acari was represented by three families: Uropodidae, Sejidae and Acaridae. Table (1) shows that the Aegyptus alhassa (Uropodidae) n. sp. was noted as parasite on RPW. Sejus sp. (Sejidae) was found in humus and litter. Also, hypopial stage of acarid mite was noted.

Aegyptus alhassa was found as a parasite on the eggs, pupae cocoons and under the elytron of RPW adult (Figs. 1-3).

\section{Aegyptus alhassa sp. nov.}

Female: Body brownish, $67.5 \mu \mathrm{m}$ long. (Fig. 4).

Gnathosoma: Tectum with one apex serrate (Fig.4a). Chelicerae with a sclerotized node behind base of movable chela, a curved process resting on the fixed digit with 5 teeth subequal in length, movable digit with 4 teeth. Laciniae flanked by a pair of smooth paralaciniae; first and third hypostomal setae simple, second and forth short.

Table (1): Mites associated with the red palm weeivl Rhynchophorus ferugineus on date palm cultivars at Al-Hassa

\begin{tabular}{lll}
\hline \multicolumn{1}{c}{ Families } & \multicolumn{1}{c}{ Species } & \multicolumn{1}{c}{ Remarks } \\
\hline Uropodidae & Aegyptus alhassa & Parasite \\
\hline Sejidae & Sejus sp. & In humus and litter \\
\hline Acaridae & Hypopial stage & $\begin{array}{l}\text { Moving stages may } \\
\text { feed on fungus or dead } \\
\text { tissue }\end{array}$ \\
\hline
\end{tabular}




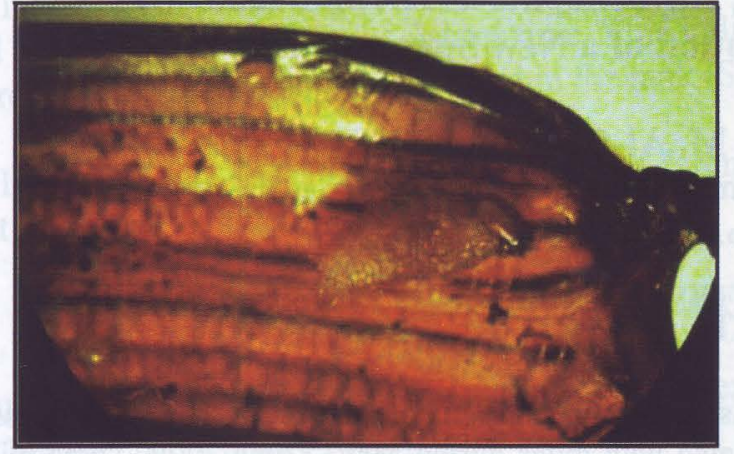

Fig. (1): Aegyptus alhassa n. sp. under the elytron (2X).

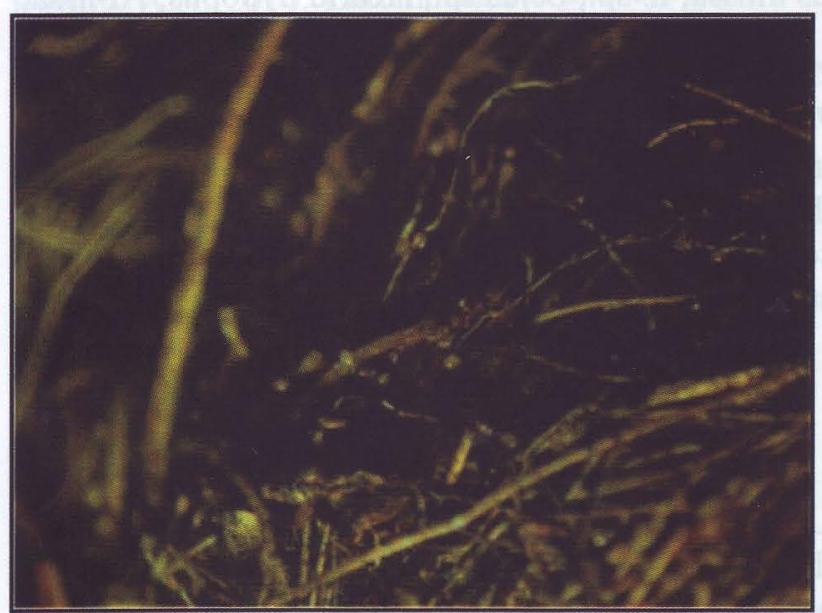

Fig. (3): Aegyptus alhassa n. sp. on pupae cocoons $(1.5 \mathrm{X})$.

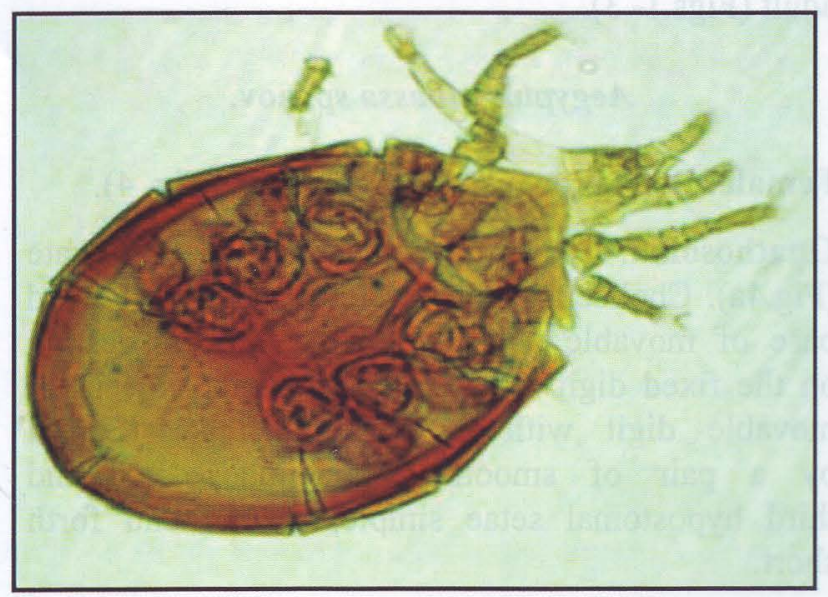

Fig. 4(b): Ventral view of female genital plate (10X).

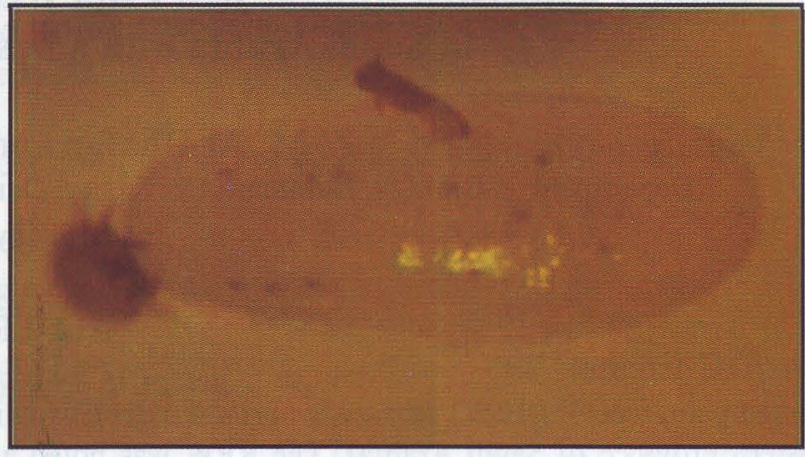

Fig. (2): Aegyptus alhassa n. sp. on egg (4X).

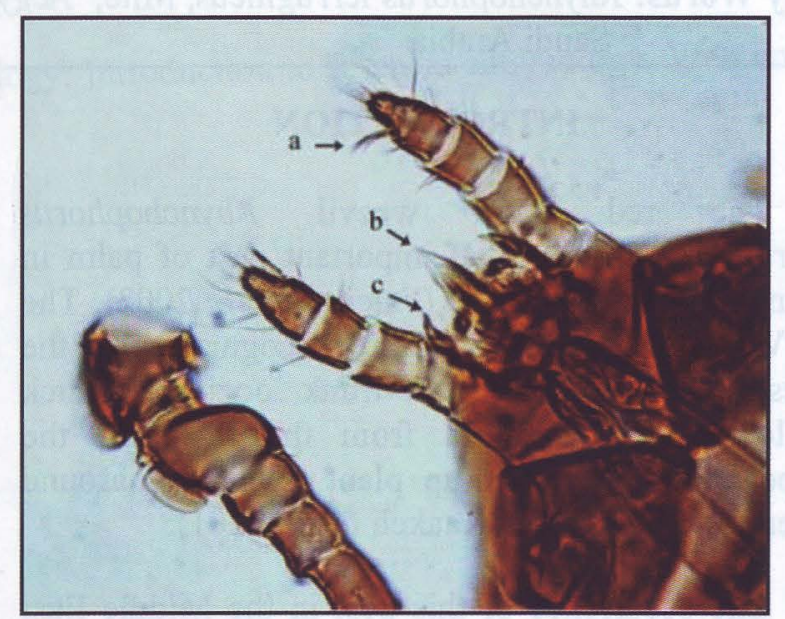

Fig. (4a): Gnathosoma ventral view of female Aegyptus alhassa n. sp. (100X)

a: Apotele of palp b: Tectum c: Paralacinia.

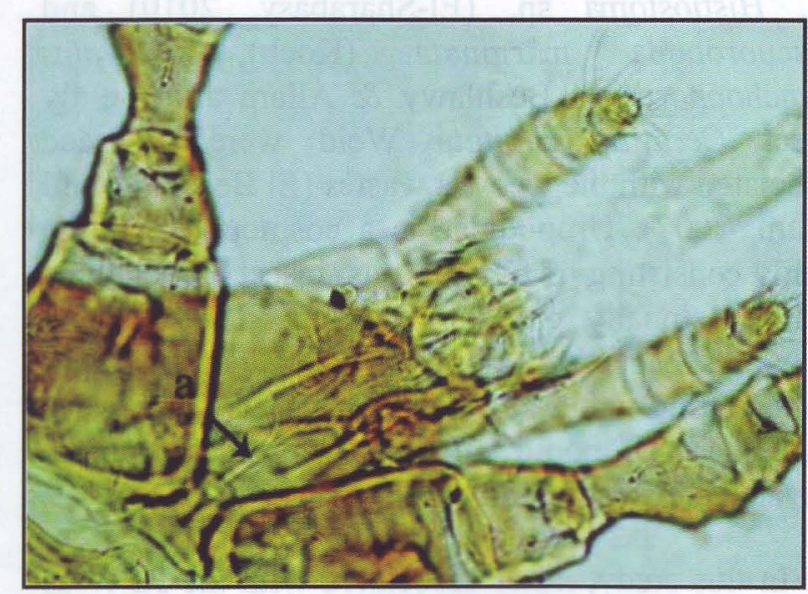

Fig. 4(c): Anterior margin of ventral view of female Aegyptus alhassa n. sp. (100X)

a: the Tritostrnum with three pilose 


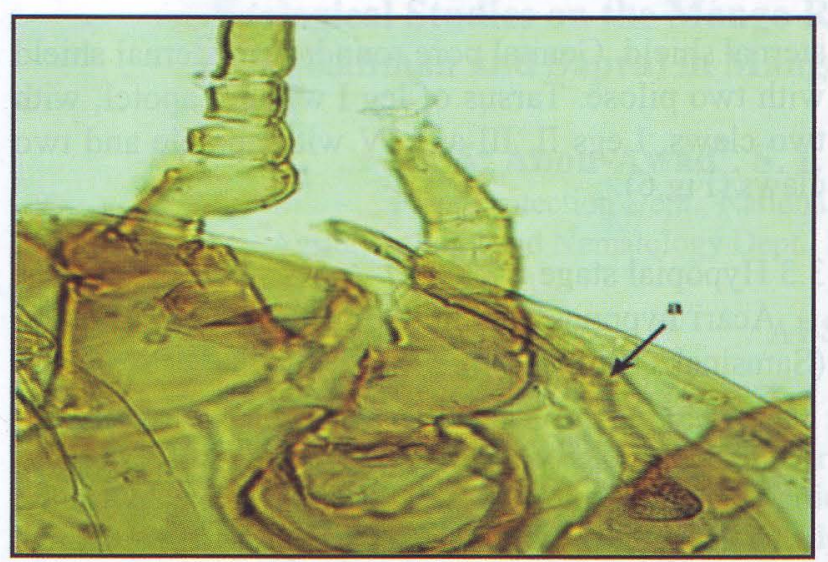

Fig. 4(d):Ventral view of Aegyptus alhassa n. sp. female (40X) a: Peritreme

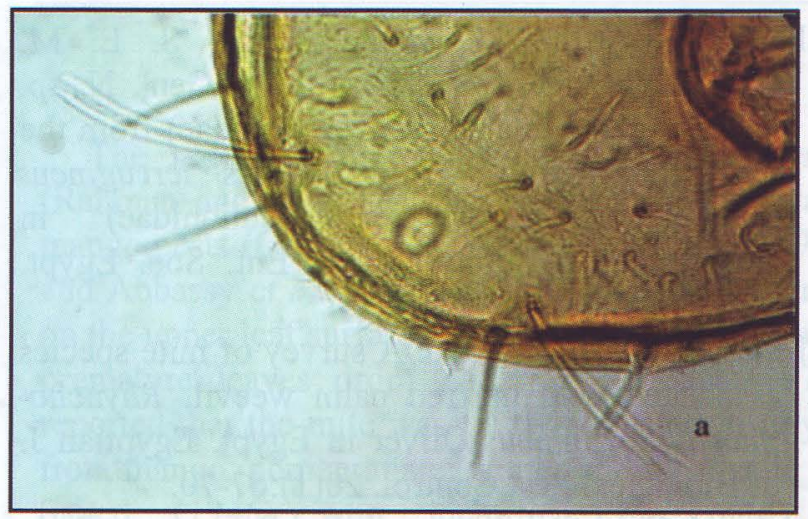

Fig. 5(b): Ventral view of Aegyptus alhassa n. sp. male $(40 \mathrm{X})$

a: Posterior margin with biramous.

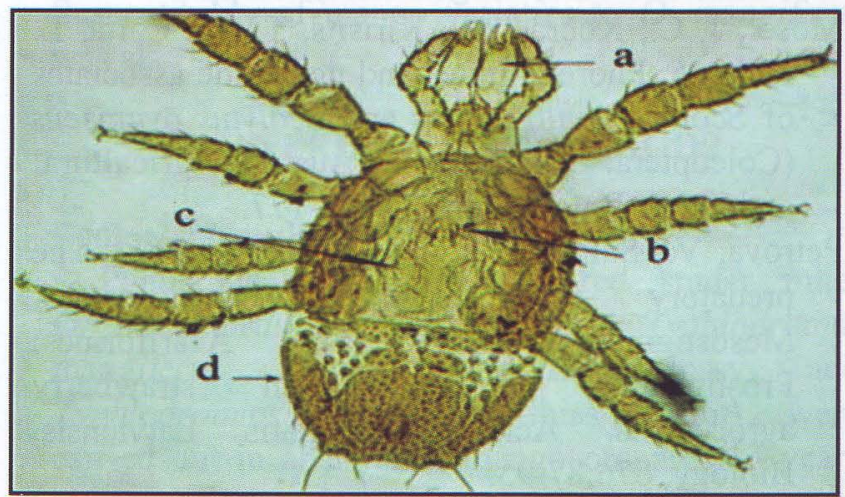

Fig. (6): Ventral view of female Sejus sp. (10X)
a : Chelicera
b : Genital pore
c : Epigynial plate
$\mathrm{d}$ : marginal plate.

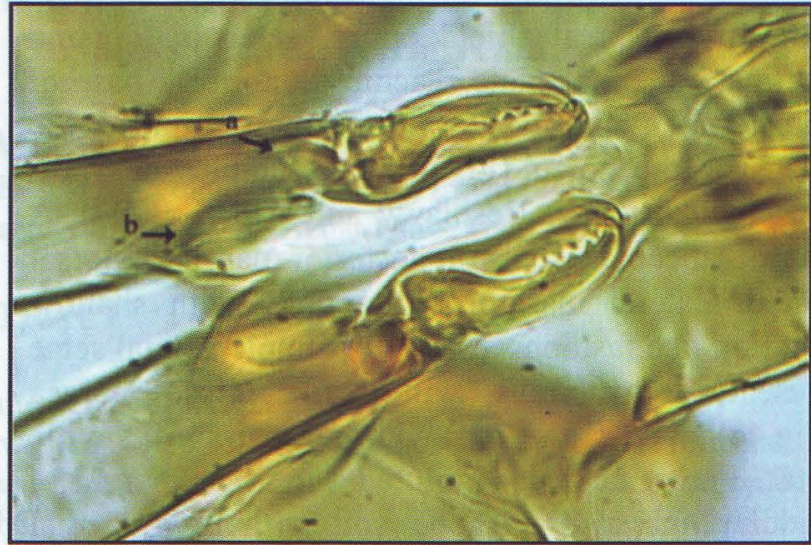

Fig. 5(a): Ventral view of male Chelicera (100X) $\mathrm{a}$ : Arthrodial brush $\quad \mathrm{b}$ : Sclerotized node

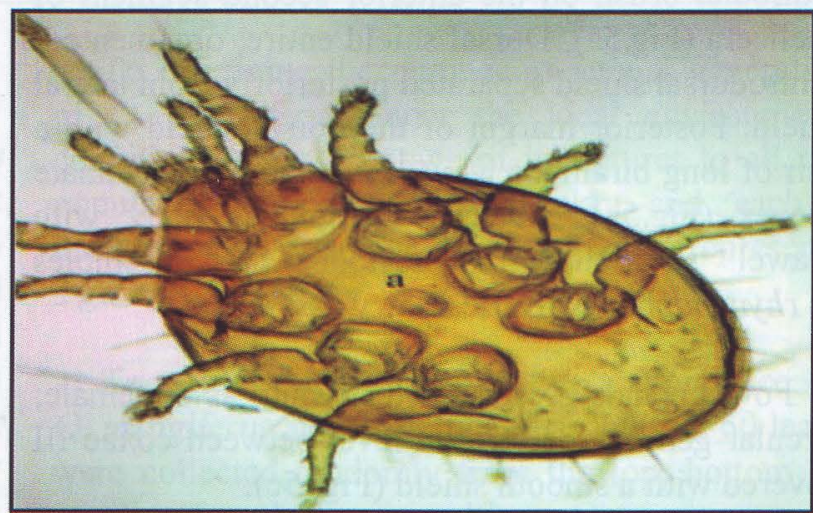

Fig. 5(c) Ventral view of male Aegyptus alhassa $(10 \mathrm{X})$

a : Genital plate

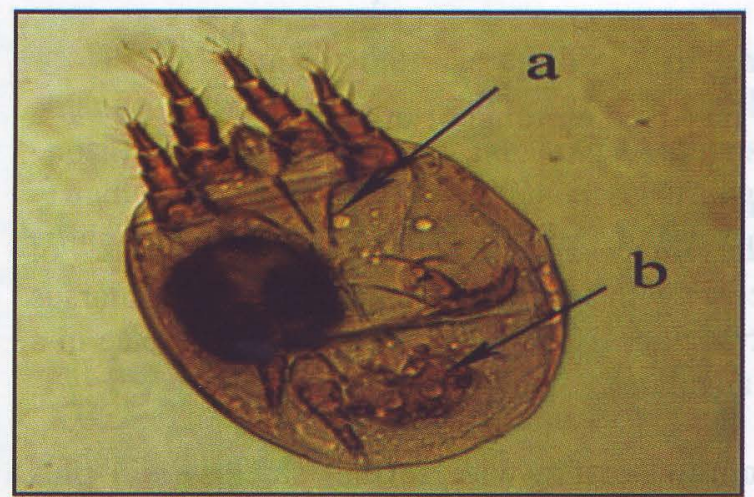

Fig. (7): Ventral view of hypopial stage (10X) a: Apodemes b: Attachment organ. 
Idiosoma: Dorsal shield entire. setae on dorsum pectinate. Genital plate reaching anteriorly base of tritosternum, anterior margin narrowly rounded, the posterior trapezoidal (Fig.4b). It resembles Aegyptus rhynchophorus (El Beshlawy and Allam, 2007). A pair of lancenlate setae on posterior margin of dorsal shield. Lateral margin of the body with shallow striation like fastoons; 3 pairs of simple genital setae present. Tritosternum with three pilose lacinea (Fig.4c). Ventral shield with 10 pairs of simple setae. Peritreme uniconvoluted, the inner margin of middle limb zigzag shape and without a medial projecting extention (Fig.4d).

Male:

Body brownish, length $60 \mu \mathrm{m}$ (Fig. 5).

Gnathosoma: As in female except in having arthrodial brush on the anterior second segment of chelicera (Fig.5a). Dorsal shield entire, ornamented; centrodorsal shield separated posteriorly from lateral shield. Posterior margin of the dorsal shield with a pair of long biramous whip-like setae with pectinate apexes (Fig.5b). Anterior margin of body with shawel striations like festoons; it resembles A rhynchophorus (El Beshlawy and Allam).

Fovae pedals present; tritosternum as in female; circular genital aperture on level between coxae III covered with a smooth shield (Fig. 5c).

Legs I and IV longer than legs II and III; trochanter and femur of leg I, femora of legs II, III and IV each with a longitudinal cres.

Members of this species were found on eggs, larvae, pupae and under elytra of adult. The mite can be transferred through the organic fertilizers mixed with soil near the base of the palm tree. This new uropodid mite is a facultative parasite.

\section{Sejus sp.}

It may feed on fungi or organic debris.

\section{Female:}

Gnathosoma: Fixed and movable digits of chelicerae with several teeth, apotele of palpal tarsus with two tines. Hypostoma with 3 pairs of setae in a subtriangular.

Idiosoma: Dorsum with several shields (six) plus two marginal plates, ornamented. Posterior margin of body with festoons. Dorsum with several setae, pectinate, epigynial shield large and not covering sternal shield. Genital pore round. Tritosternal shield with two pilose. Tarsus of leg I without apotel, with two claws. Legs II, III and IV with apotele and two claws (Fig.6).

\subsection{Hypopial stage}

Acari hypopus was noted on the weevil (Fig. 7) (Samsinak, 1965).

\section{ACKNOWLEDGMENT}

The authors would like to express their thanks to Prof. Dr. Laila M. Oyoun, Professor of parasitology, Science College of Dammam (KSA) for identification the mites and manuscript preparation.

\section{REFERENCES}

El Beshlawy, Sh. M. O.and Allam, S. E. M. 2007. Aegyptus rhynchophorus, N. Gen., N. sp. (Acrari Uropodina : Trachyuropodidae) from the red palm weevil, Rhynchophotus ferrugineus (Olivier), (Coleoptera, Curculionidae) in Egypt. Proc. $2^{\text {nd }}$ Inter. Conf. Ent. Soc. Egypt, 1: 421-433.

El-Sharabasy, H. M. 2010. A survey of mite species associated with the red palm weevil, Rhynchophorus ferrugineus Oliver in Egypt. Egyptian J. of Biological Pest Control, 20(1):67-70.

Faleiro, J. R.; Ashak Kumar, J. and Rangnenar, P. A. 2002. Spatial distribution of red palm weevil, Rhynchophorus ferrugineus Oliv. (Coleoptera: Curculioldae). Crop Protect. 21: 171-176.

Kaakeh, W.; Khamis, A. and Aboul-Naour, M. M. 2001 The red palm weevil, the most dangerous agricultural pest. UAE University, $164 \mathrm{pp}$.

Kramtz, G. W. 1968. A mammal f Acarology. Seond Edition (Oregon State University- Sity Book stores: Corvallis, Oregon USA, 509 pp.

Moser, J. C.; Konrad, H.; Kirisits, T. and Carta, L. K. 2005. Phoretic mites and nematode associates of Scolytus multistriatus and Scolytus pygmaeus (Coleoptera: Scolytidae) in Austria. Agricultural and Forest Entomology, $7:$ 169-177.

Petrova, V.; Salmane, I. and Cudare, Z. 2004. The predatory mites (Acari. Parasitiformes: Mesostigmata (Gamasina): Acariformes: Prostigmata) community in strawberry agrocenosis. Acta Lniversitatis Latviensis, Biology, 676:87-95.

Samsinak, K. 1965. Termiture Milben aus der VR china, 2. Acaris Re? Reichenbachia, 5 (34): 291-294. 